References

1. Stein, D.K. \& Sugar, A.M. Fungal infections in the immunocompromised host. Diagn Microbiol Infect Dis 1989, 12: $221 \mathrm{~S}-228 \mathrm{~S}$.

2. Denning, D.W. \& Stevens, D.A. Antifungal and surgical treatment of invasive aspergillosis: review of 2,121 published cases. Rev Infect Dis 1990, 12: 1147-1201.

3. Klimowski, L.L., Rotstein, C. \& Cummings, K.M. Incidence of nosocomial aspergillosis in patients with leukaemia over a twenty year period. Infect Control Hosp Epidemiol 1989, 10: 299-305.

4. Denning, D.W., Follansbee, S.E., Scolaro, M., Norris, S., Edelstein, H. \& Stevens, D.A. Pulmonary aspergillosis in the acquired immunodeficiency syndrome. N Engl J Med 1991, 324: 654-662.

5. Cook, D.J., Achong, M.R. \& King, D.E. Disseminated aspergillosis in an apparently healthy patient. Am J Med 1990, 88: 74-76.

6. Bodey, G.P. \& Vartivarian, S. Aspergillosis. Eur J Clin Microbiol Infect Dis 1989, 8: 413-437.
7. Eisenstein, D.J., Biddinger, P.W. \& Rhodes, J.C. Experimental murine invasive pulmonary aspergillosis. Am J Clin Path 1990, 93: 510-515.

8. Spreadbury, C.L., Krausz, T., Pervez, S. \& Cohen, J. Invasive ${ }^{C}$. aspergillosis: clinical and pathological features of a new animal model. J Med Vet Mycol 1989, 27: 5-15.

9. Zimmerci, W., Zarth, A., Gratwohl, A. \& Speck, B. Neutro-으 phil function and pyogenic infection in bone marrow trans $-\bar{O}$ plant recipients. Blood 1991, 77: 393-399.

10. Robertson, M.D., Seaton, A. \& Raeburn, J.A. Phagocytic cell responses to Aspergillus fumigatus. FEMS Microbioß口 Immunol 1989, 47: 305-306.

11. Robertson, M.D., Kerr, K.M. \& Seaton, A. Killing of aspergillus fumigatus spores by human lung macrophages, $\mathrm{aO}$ paradoxical effect of heat labile serum components. $J \mathrm{Med}-$ Vet Mycol 1989, 27: 295-302.

12. Weiss, S.J. Tissue destruction by neutrophils. $N$ Engl J Med 1989, 320: $365-376$.

\title{
Parathyroid crisis and acute viral hepatitis B infection
}

\author{
Hugh E. Mulcahy, Frank E. Murray, Rosemarie Freaney ${ }^{1}$ and \\ John E. Hegarty
}

Gastroenterology and Liver Unit and ${ }^{1}$ Metabolic Unit, St Vincent's Hospital, Elm Park, Dublin 4, Irelan

\begin{abstract}
Summary: The simultaneous development of acute hyperparathyroidism and viral hepatitis B infection in a 72 year old male is described. Resolution of the hepatitis was accompanied by improvement in the parathyroid hormone mediated hypercalcaemia. It is postulated that antibodies to the hepatitis B virus may have altered the calcium 'set point' allowing uncontrolled synthesis and release of parathyroid hormone during the acute illness.
\end{abstract}

\section{Introduction}

Hypercalcaemia, a rarely recognized complication of acute viral hepatitis has been reported in association with acute non-A non-B hepatitis and attributed to virus-induced cytokine production. ${ }^{1}$ Acute primary hyperparathyroidism (parathyroid crisis) has been described as an unusual form of hyperparathyroidism characterized by life-threatening hypercalcaemia ${ }^{2}$ and has not previously been reported in association with viral hepatitis.

\section{Case report}

A 71 year old man was admitted with a 3 week history of anorexia, nausea, vomiting, malaise,

Correspondence: H. Mulcahy, M.B., M.R.C.P.I.

Accepted: 2 November 1992 fatigue, arthralgia, myalgia and polyuria. A benign gastric ulcer and reflux oesophagitis, confirmed? endoscopically, had been diagnosed 9 months previously and successfully treated with ranitidine? $150 \mathrm{mg}$ twice daily for 8 weeks. There was no history of transfusion with blood or blood products, homosexual contact, alcohol abuse, hep- N atotoxic drug ingestion, recent foreign travel, ingestion of antacids, lithium, thiazides, vitamin $D_{N}$ or calcium-containing preparations. At presenta- $\omega$ tion physical examination revealed jaundice and hepatomegaly in the absence of stigmata of chronico liver disease.

\section{Results}

Investigations revealed a serum albumin of $33 \mathrm{~g} / 1 \stackrel{\mathrm{P}}{\mathrm{P}}$ (normal range: $35-50$ ), bilirubin $85 \mathrm{mmol} / 10$ 
(4-17), aspartate transaminase $580 \mathrm{IU} / 1(8-40)$, alanine transaminase $700 \mathrm{IU} / 1$ (5-42), alkaline phosphatase 109 IU/1 (30-110) and gamma glutamyl transferase $143 \mathrm{IU} / 1(0-50)$ as determined by standard laboratory techniques. Serological analysis revealed hepatitis $B$ surface $(\mathrm{HBs})$ and e $(\mathrm{HBe})$ antigens (Abbott, UK) and antibodies to IgM HBc (HB core) (Amersham International, UK). Primary hyperparathyroidism was diagnosed on the basis of a raised serum intact parathyroid hormone (PTH) of $16.1 \mathrm{pmol} / 1$ (0.2-5.5; Allegro PTH, Nichols Institute) and a raised serum ionized calcium $1.62 \mathrm{mmol} / 1$ (1.19- 1.33; analyte + 2, Baker). Parathyroid function tests performed during the acute hepatitis B infection and 6 months later are shown in Table I. Serum $25-\mathrm{OH}$ vitamin D was less than $5 \mathrm{nmol} / 1$ (14-79) and serum 1,25 $(\mathrm{OH})_{2}$ vitamin D was $69 \mathrm{pmol} / 1(38-144)$. Renal function was normal with a serum creatinine of $0.11 \mathrm{mmol} / 1(0.06-0.115)$ and a creatinine clearance of $75 \mathrm{ml} / \mathrm{minute}$. Thyroid stimulating hormone was $1.4 \mathrm{mU} / \mathrm{ml}(0.15-3.2)$. There was no evidence of ectopic calcification, hyperparathyroid or metastatic bone disease on skeletal survey. Chest $\mathrm{X}$-ray was normal. Leucocyte and red cell count was normal and erythrocyte sedimentation rate was $8 \mathrm{~mm}$ /hour.

\section{Subsequent course}

Treatment was commenced with intravenous saline infusions which were continuously required over a 3 week period to prevent life-threatening hypercalcaemia. With resolution of the clinical and biochemical features of acute hepatitis, the serum calcium returned towards normal (Figure 1). Reevaluation at 6 months confirmed a diagnosis of primary hyperparathyroidism with a mildly elevated serum ionized calcium and an inappropriately 'normal' serum parathyroid hormone level (Table I).

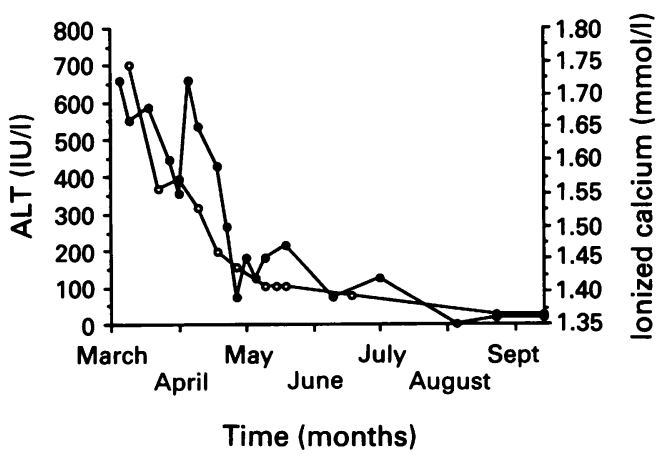

Figure 1 Serum ionized calcium and ALT levels during the course of acute hepatitis $B$ infection. $-\mathrm{O}_{-}=\mathrm{ALT}$ $(\mathrm{IU} / \mathrm{l}) ;-\mathrm{O}_{-}=$serum ionized calcium $(\mathrm{mmol} / \mathrm{l})$.

\section{Discussion}

The results indicate the simultaneous development of hepatitis B viral infection and acute hyperparathyroidism. The liver plays an important role in the metabolism of PTH, cleaving PTH (1-84) into N-terminal PTH $(1-34)$ and biologically inactive $\mathrm{C}$-terminal peptide. ${ }^{3}$ Both $\mathrm{N}$-terminal and whole hormone PTH $(1-84)$ are biologically active as the structural requirement for activity resides in the first 34 amino acids. There is, therefore, no requirement for cleavage of whole hormone for biological activity to be expressed. The kidneys also convert intact hormone to PTH $(1-34)$ and Cterminal peptide. It is unlikely, therefore, that decreased liver catabolism of PTH (1-84) is responsible for the hypercalcaemia in this patient as increased renal metabolism may compensate for any excess circulating PTH arising as a result of severe hepatocellular necrosis.

Raised liver enzymes in a patient with subacute thyroiditis has been reported, ${ }^{4}$ liver enzymes returning to normal in association with resolution of the thyroiditis. Viral thyroiditis may result from

Table I Metabolic indices during and 6 months after acute hepatitis B viral infection

\begin{tabular}{lccc}
\hline & Reference range & At presentation & At 6 months \\
\hline Total calcium (mmol/l) & $2.25-2.65$ & 3.67 & 2.79 \\
Ionized calcium (mmol/l) & $1.19-1.33$ & 1.72 & 1.36 \\
Phosphate (mmol/l) & $0.8-1.4$ & 0.72 & 0.96 \\
Serum PTH (pmol/l) & $0.2-5.5$ & 16.1 & 4.7 \\
Urinary CAMP (nmol/l) & $12.8-38.8$ & 75.8 & 31.9 \\
Nephrogenous CAMP (nmol/l) & $0-26$ & 47.5 & 16.7 \\
TmPO 4 /GF (mmol/l) & $0.81-1.39$ & 0.37 & 1.57 \\
Serum 25(OH)D (mmol/l) & Feb/March & $<5$ & \\
& $14-79$ & & 63.3 \\
& Aug/Sept & & \\
Serum 1,25(OH) ${ }_{2} \mathrm{D}(\mathrm{pmol} / \mathrm{l})$ & $36-90$ & 69 & \\
\hline
\end{tabular}


release of a significant quantity of stored thyroid hormone. Stores of PTH are limited in comparison with those of other endocrine glands, and are only sufficient to meet basal secretory needs for approximately 6 hours. ${ }^{5}$ Under conditions of maximal stimulation, PTH stores become exhausted after only $1 \frac{1}{2}$ hours without an increased rate of hormone synthesis. The sudden release of stored PTH would not cause an aggressive hypercalcaemic phase of 6 weeks duration as was evident in this case.

PTH enhances the activity of the $1-\alpha$-hydroxylase enzyme responsible for the conversion of 25 $(\mathrm{OH})$ vitamin $\mathrm{D}$ to $1,25(\mathrm{OH})_{2}$ vitamin $\mathrm{D}$. The normal $1,25(\mathrm{OH})_{2}$ vitamin $\mathrm{D}$ reported in this patient despite the stimulus of a high circulating PTH may have resulted from lack of precursor 25 $(\mathrm{OH})$ vitamin $\mathrm{D}$ during the acute phase of the illness. It may have also contributed to the raised PTH and concomitant hypercalcaemia by not exerting the normal feedback control on PTH synthesis. The hypovitaminosis $\mathrm{D}$ recorded initially was more likely to be due to a deficiency state $^{6}$ rather than as a result of hepatitis, as 25-hydroxylation can be maintained in the presence of significant liver disease. ${ }^{7}$

\section{References}

1. Ford, D.J. \& Reid, I.R. Hypercalcaemia associated with viral hepatitis (letter). Lancet 1991, 336: 181.

2. Fitzpatrick, L.A. \& Bilezikian, J.P. Acute primary hyperparathyroidism. Am J Med 1987, 82: 275-282.

3. Martin, K.J., Hruska, K.A., Freitag, J.J., Klahr, S. \& Slatopolsky, E. The peripheral metabolism of parathyroid hormone. $N$ Engl J Med 1979, 301: 1092-1098.

4. Kimura, M., Amino, N., Takada, K. \& Miyai, K. Subacute thyroiditis associated with systemic multi-organ disorders. Endocrinol Jpn 1989, 36: 859-864.

5. Habener, J.F. \& Pott, J.T., Jr. Biosynthesis of parathyroid hormone. N Engl J Med 1978, 229: 635-643.

6. McKenna, M.J., Freaney, R., Meade, A. \& Muldowney, F.P. Hypovitaminosis D and elevated serum alkaline phosphatase in elderly Irish people. Am J Clin Nutr 1985, 41: 101-109.
The point at which extracellular calcium concen- $-\frac{0}{0}$ tration suppresses PTH synthesis and release from $\cong$ the parathyroid glands is known as the 'set point'. $\frac{\overrightarrow{\mathbb{D}}}{\mathrm{C}}$

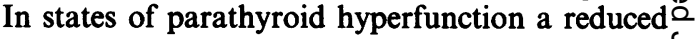
sensitivity to the suppressive effect of extracellular $\stackrel{C}{-}$ calcium, or raising of the set point may occur $\stackrel{8}{\stackrel{\vec{m}}{\overrightarrow{0}}}$ Recognition of changes in extracellular calciumconcentration are detected by cell surface receptors $\frac{\bar{O}}{-}$ on parathyroid gland cells, and substances which $\overline{\bar{m}}$ bind to these receptors may alter the calcium set $\widehat{\varnothing}$ point. Posillico has shown that monoclonal antibodies may block the inhibitory effect of cal- $\infty$ cium on PTH secretions. ${ }^{9}$ Antibodies produced $\vec{O}$

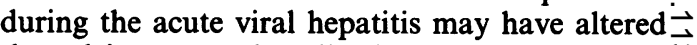
the calcium set point allowing uncontrolled syn- $\omega$ thesis and release of PTH, with consequent life-threatening hypercalcaemia.

\section{Acknowledgements}

The authors wish to thank Dr M.J. McKenna and DrT J McKenna for helpful discussion during the preparation? of this manuscript.

7. Posner, D.B., Russell, R.M., Absood, S. et al. Effect 25-hydroxylation of vitamin D2 in alcoholic cirrhosis. Gast Fo enterology 1978, 74: 866-870.

8. Leboff, M.S., Shoback, D., Brown, E.M. et al. Regulation of parathyroid hormone release and cytosolic calcium by extra- $\mathbb{D}$ cellular calcium in dispersed and cultured bovine and 2 pathological human parathyroid cells. J Clin Invest 1985, 75: $\overrightarrow{\overline{0}}$ 49-57.

9. Posillico, J.T., Srikanta, S., Eisenbarth, G. et al. Binding of $\frac{-}{\partial}$ monoclonal antibody (4F2) to its cell surface antigen on dispersed adenomatous parathyroid cells raises cytosolic calcium and inhibits parathyroid hormone secretion. J Clin Endocrinol Metab 1987, 64: 43-50. 